\title{
Comparative Performance of Linear Spectral Mixture \& NDVI Technique by Mapping Sediment Yield using Semmed Model
}

\author{
J. M. Ghetiya ${ }^{1^{*}}$ and G. R. Patel ${ }^{2}$ \\ ${ }^{1}$ College of Agricultural Engineering and Technology, Godhra, India \\ ${ }^{2}$ Department of Soil and Water Conservation Engineering, Godhra, India \\ *Corresponding author
}

\section{A B S T R A C T}

\begin{tabular}{l}
\hline Ke y w or d s \\
Soil erosion model, \\
Spectral mixture \\
Analysis, \\
SEMMED model, \\
Spectral mixing \\
\hline Article Info \\
$\begin{array}{l}\text { Accepted: } \\
12 \text { March } 2020 \\
\text { Available Online: } \\
10 \text { April } 2020\end{array}$ \\
\hline
\end{tabular}

Soil erosion is one of the most attentive issues everywhere. The $\mathrm{C}$ factor expresses with the impacts of vegetation shelter and ground covers in reducing soil loss. This investigation displays another methodology dependent on Linear Spectral Mixture Analysis (LSMA) of Landsat information to delineate $\mathrm{C}$ factor for use in the demonstrating of soil erosion. An interesting component of LSMA is that it assesses the fragmentary wealth of ground shelter and exposed soils all the while, which is fitting for soil erosion investigation. Thus, we evaluated the $\mathrm{C}$ factor by using the result of LSMA on a pixel-by-pixel premise. LISS - III picture was utilized for vegetation and ground shelter estimation. Meteorological information were gotten from the State Water DataCenter (SWDC), Gandhinagar for the year of 2008 and 2015. Normalized Difference Vegetation Index (NDVI) was utilized for comparative analysis. The estimated sediment yield of the watershed using LSMA technique was found to be 11.30 and $13.5 \mathrm{t} / \mathrm{ha} / \mathrm{yr}$ and using NDVI technique was found to be 14.01 and $15.2 \mathrm{t} / \mathrm{ha} / \mathrm{yr}$ for the year of 2008 and 2015, respectively. Comparative analysis of NDVI and LSMA-derived C-factors also proved that the LSMA generated more accurate erosion estimates for this study area when used as input to SEEMED model. So the LSMA strategy is smarter to use than the NDVI method.

\section{Introduction}

Erosion is the process of detachment and transport of soil particle by wind, rain and runoff. The most unaffected kind of erosion is found in sloping regions, predominantly erosion from uneven and free geographical material that prompts gully erosion and the mass development of soil and shakes (Bagherzadeh and Daneshvar, 2013). In India, very nearly $130 \mathrm{M}$ ha of land that is $45 \%$ of all-out topographical region influenced by genuine soil erosion through a ravine, moving developing, developed no man's land, sandy lands, deserts and waterlogging.

Around one millimeter of topsoil is being lost each year with an all-out loss of 5334 million tons every year because of soil erosion (Srinivasa Rao, 2012). GIS provides a digital representation of the catchment which can be used in hydrological modelling. A GIS can be 
used to scale up to regional levels and to quantify the differences in soil loss estimates produced by different scales of soil mapping used as a data layer in the model.

The estimation of sediment yield at the catchment scale is very complex because of huge information necessity, constrained learning of complex procedures included and the association between these procedures (De Vente et al., 2005). Modelling only can give a quantitative and reliable way to deal with measure soil erosion and sediment yield under a wide scope of conditions. The Universal Soil Loss Equation (USLE) is the most straightforward empirical model for erosion calculation, which measures long period average yearly soil loss with adequate precision (Beskow et al., 2009).

There are several physically-based models accessible for sediment calculation, for example, Erosion Productivity Impact Calculator (EPIC) (Williams et al., 1984) and Agricultural Non-Point Source Pollution Model (AGNPS) (Young, 1987), Areal NonPoint Source Watershed Environment Response Simulation ANSWERS (Beasley et al., 1980), Water Erosion Prediction Project WEPP (Nearing et al., 1989), Kinematic Runoff and Erosion model KINEROS (Woolhiser et al., 1990) and European Soil Erosion model EUROSEM (Morgan, 1998).

SEMMED model is most appropriate for small watershed zone for sediment yield assessment. The model considers soil erosion to result from the component of soil particles by raindrop power and the conveyance of these particles by the overland flow (De Jong et al., 1999).

Vegetation and soil properties, these two elements are influencing the different phases of soil erosion and their related changes through time and space. The linear mixture model (LMM) approach is one of the frequently utilized strategies for taking care of the mixed pixel issue. It assesses every pixel range as a direct mixture of a lot of end member spectra (Lu et al., 2003). SMA measures small abundance of land shelter sections utilizing end-members, which express to the spectral qualities of land shelter classes (De Asis et al., 2008).

The LSMA was also discovered valuable in assessing the percentage of ground shelters, for example, crop deposits, which also play a main roll in controlling soil erosion (Alejandro and Omasa 2007).

Thinking about all the above certainties, the present research on ordering the land sat picture to examine land spread and vegetation mark by utilizing spectral mixture modelling techniques in a GIS environment, get to the overland flow and evaluate the sediment yield by using distributed model in a small watershed.

\section{Materials and Methods}

\section{Description of study area}

The area selected for the present study is Limkheda agricultural watershed. This area located in the semi-arid middle region of Gujarat, India (Fig. 1). The total area of the Limkheda watershed is about $218.66 \mathrm{~km}^{2}$. The study area is located at latitude $22^{\circ} 49^{\prime}$ $55^{\prime \prime}$ and longitude $73^{\circ} 59^{\prime} 15^{\prime \prime}$.

The average annual rainfall in the study area (Limkheda watershed) is $660 \mathrm{~mm}$. Watershed being situated in semi-arid region and dominated with agriculture and forest land. In Limkheda watershed maximum temperature varies from $25^{\circ} \mathrm{C}$ to $44^{\circ} \mathrm{C}$ and minimum temperature varies from $6^{\circ} \mathrm{C}$ to $28^{\circ} \mathrm{C}$. Relative humidity varies from 46 to $100 \%$. Wind speed varies from 0.01 to $21.32 \mathrm{~km} / \mathrm{hr}$. 


\section{Data collection}

There are many types of data required for estimation of sediment yield. Meteorological data was obtained from the State Water Data Center (SWDC), Gandhinagar for the year of 2008 and 2015. The soil map were collected from FAO Digital Soil Map of the World (DSMW) which was prepared on a scale 1:5,00,000 scale.

Land use / Land cover map were prepared from satellite imageries. Other required input maps such as slope map, flow direction map, flow accumulation map, drainage network map were prepared in Arc Map GIS software environment.

\section{Linear spectral mixture analysis (LSMA)}

Spectral Mixture Analysis (SMA) has frequently been represented to manage the issue of mixed pixels. Linear SMA models have additionally been verified to be sensibly convincing in assessing end-member divisions and broadly utilized because of their smoothness, sensible capability and interpretability (De Jong et al., 1999).

The fundamental assumption of the unmixing method is that the spectral sign by the satellite sensor is for every pixel a straight mixture of spectral marks of pure parts weighted by their productivity in that pixel (De Jong et al., 1999; Alejandro and Omasa, 2007). An endmember is a pure surface material or land spread class that is expected to have an interesting spectral signature. Numerically, the general type of the LSMA is:

$$
\begin{aligned}
& \mathbf{R}_{\mathbf{i}}=\sum_{n=1}^{n}\left(\mathbf{F}_{\mathbf{j}} \mathbf{R E}_{\mathrm{ij}}\right)+\varepsilon_{\mathbf{i}} \\
& \sum_{n=1}^{n} \mathbf{F}_{\mathbf{j}}=\mathbf{1} ; 0 \leq \mathrm{F} \leq 1
\end{aligned}
$$

Where,

$R_{i}$ is the reflectance value of a pixel in band $\mathrm{i} ; \mathrm{F}_{\mathrm{j}}$ is the fraction of end member $\mathrm{j}$ (in terms of percentage of the pixel surface); $R E_{i j}$ is the reflectance value for band $i$ of end member $j$; $\varepsilon_{i}$ is the residual error in band $i$ and $n$ is the number of bands

These are the fractions across all endmembers sum to one, and individually endmember fraction is in the range 0 to 1 (Alejandro and Omasa, 2007). The determination of reasonable end-members is the most thoughtful in the improvement of top class fraction pictures.

There are various techniques for choosing end members from the picture. In this examination, minimum noise fraction (MNF) algorithm was associated to the reflectance picture in which the MNF changed information was utilized as contribution to decide the most spectrally pure pixels in the picture.

Four unique end-members were distinguished in this investigation: agriculture, bare soil, forest and water. Agriculture comprises of crops, grasses, bushes and etc. The bare soil comprises of industrialized region and nearly uncovered soil. The forest comprises of little teak wood plants and eucalypts. The last end part determination is water.

The output of spectral unmixing comprised of the division picture of each chosen end-part (agriculture, bare soil, forest and water) and a Root Mean Square Error (RMSE). The fraction pictures (with the exception of water) were then utilized in deciding the $\mathrm{C}$ factor.

The fraction water $(\mathrm{Fw})$ was separated by rescaling the three land cover divisions (vegetation, bare soil and forest) with the standardization factor. 


\section{C factor estimation}

\section{Linear spectral mixture analysis (LSMA) derived C- factor}

Alejandro and Omasa (2007) utilizing little plots to estimate soil erosion under different ground covers in the Philippines, announced an exponential increment in yearly soil loss with reducing ground cover, though the more uncovered soil or exposed soil the higher soil erosion. Using this idea, Alejandro and Omasa (2007) utilized the fragmentary abundance of uncovered soil and ground spread (as decided from the LSMA) to characterize the $\mathrm{C}$ factor on a pixel-by-pixel premise as pursues:

$$
c=\frac{\text { Fbs }}{1+\text { Fag }+ \text { Ff }}
$$

Where, $F_{b s}=$ fraction of bare soil, $\mathrm{F}_{\mathrm{ag}}=$ fraction of agriculture, $F_{f}=$ fraction of forest

The expansion of 1.0 in as far as possible the $\mathrm{C}$ values from 0 to 1 with higher qualities showing increasingly uncovered soil, and lower values comparing to a high wealth of vegetation or ground spread. Utilizing the above condition, a $\mathrm{C}$ factor map was generated and used for SEMMED model input and compared with NDVI derived C factor.

\section{Normalized difference vegetation index (NDVI) derived C- factor}

The most well-known system for evaluating $\mathrm{C}$ factor utilizing the NDVI (Alejandro and Omasa, 2007) includes the utilization of regression equation model got from the relationship investigation between the $\mathrm{C}$ factor values estimated in the field and a satellite-determined NDVI (De Jong et al., 1999). The visible and near infrared bands on the satellite multispectral sensors permit checking of the greenness of vegetation. The NDVI communicates the contrast between reflectance in the red and near infrared (nir) bands. Utilizing the LISS III satellite picture, the NDVI was figured using band 2 (red) and band 3 (nir) as pursues:

$$
C=\frac{\text { Band3 }- \text { Band2 }}{\text { Band3 }+ \text { Band2 }}
$$

Where,

Band2 $=$ spectral reflectance of red band, Band $3=$ spectral reflectance of near infrared band

Using the above equation $\mathrm{C}$ factor map was generated and used for SEMMED model input and compared with the LSMA derived $\mathrm{C}$ factor.

\section{Soil erosion model for Mediterranean regions (SEMMED)}

SEMMED estimates soil loss on a yearly premise. The model considers soil erosion to result from the unit of soil particles by raindrop power and the carriage of these particles by overland flow. The Morgan, Morgan and Finney technique to anticipate yearly soil loss (Morgan et al., 1984) yielded the physical reason for SEMMED yet was changed to show the erosion procedure following a dispersed methodology and to empower the contribution from satellite pictures and DEMs.

The model used to coordinate the different information sources, satisfies certain conditions a) the model ought to be founded on the ideas of the erosion procedure, $b$ ) the scale at which the model works should coordinate the spatial resolution of the earth perception pictures and the DEM, c) the model ought to dependably virtual the detached character of the erosion procedure, 
and d) the model ought to be approved under a scope of natural conditions (De Jong et al., 1999). The every module are nonexclusive and simple to execute in a regular GIS. The particular methodology, appeared in Fig. 2, keeps the model straightforward and limits the quantity of required info factors.

\section{Model development}

In the present study, estimation of soil erosion by water was modelled by using SEMMED model. In this approach detachment of soil particles by raindrop power and the carriage of these particles by overland flow were taken into account for soil erosion calculation.

The model uses eight operating functions for which different input parameters are required. The model splits the soil erosion method into a water segment and a sediment segment.

\section{Water segment}

In the water phase the kinetic energy of the rainfall and the volume of overland flow are computed. The model starts with rainfall energy calculation. Kinetic energy $\left(E\right.$ in $J / \mathrm{m}^{2}$ ) of rainfall is measured using yearly rainfall ( $R$ in $\mathrm{mm}$ ) and a typical value for intensity of erosive rain (I in $\mathrm{mm} / \mathrm{hr}$ ) as proposed by Morgan et al., (1984):

$$
\mathrm{E}=\mathrm{R}\left(11.9+8.7 \log _{10} \mathrm{I}\right)
$$

Next, When the top-soil moisture capacity is surpassed, the extra rainfall, defined as the rainfall which is neither reserved on the land surface nor entered into the soil, becomes overland flow until it is depleted in one of the catchment channels.

Consequently, overland flow ( $Q$ in $\mathrm{mm})$ per raster cell is estimated from the mean precipitation per precipitation day in the year ( $R$ in $\mathrm{mm} /$ day) and from the critical value for soil moisture storage limit $\left(R_{c}\right.$ in $\left.\mathrm{mm}\right)$ following De Jong et al., (1999):

$$
\mathrm{Q}=\mathrm{R} \exp \left(-\mathrm{R}_{\mathrm{C}} / \mathrm{R}_{0}\right)
$$

Rc is computed from the soil moisture (MS) content in (\% w/w)as proposed by Allen et al., (2005), bulk density (BD) of the top soil (in $\mathrm{g} / \mathrm{m}^{3}$ ), rooting depth (RD) of A- horizon (in $\mathrm{m}$ ) and ratio of actual to potential evapotranspiration $\left(\mathrm{E}_{\mathrm{t}} / \mathrm{E}_{0}\right)$ proposed by Mehta and Pandey, (2016):

$$
\mathrm{R}_{\mathrm{C}}=1000 * \mathrm{MS} * \mathrm{BD} * \mathrm{RD} *\left(\mathrm{E}_{\mathrm{t}} / \mathrm{E}_{0}\right)^{0.5}
$$

For each separate raster cell the soil moisture storage limit is determined. Mean precipitation per precipitation day $\left(\mathrm{R}_{0}\right)$ is estimated by dividing the yearly precipitation volume $(\mathrm{R})$ by the number of precipitation days $\left(R_{n}\right)$.

$$
\mathrm{R}_{0}=\mathrm{R} / \mathrm{R}_{\mathrm{n}}
$$

From the produced overland flow per raster cell, a spread overland flow map is computed. The overland flow per raster cell is computed by combining yearly precipitation, mean precipitation per precipitation day and the soil moisture storage limit.

\section{Sediment segment}

After estimated overland flow the channel direction of each particular cell is calculated from the DEM. Then geomorphological routing algorithm is useful to estimate a 'cumulative overland flow' map. The distributed transport capacity (DT) is then computed from the cumulative overland flow (CF in $\mathrm{mm}$ ).

For compute distributed transport capacity, the map with the quantity of created overland flow per raster cell is joint with the map of cumulative overland flow and subtracting a 
map with the saturated infiltration capacity (Ks in $\mathrm{mm} /$ day) per cell. Then joint with the slope map ( $\mathrm{S}$ in degrees) after covering the hydrological network by using binary overlay $(\mathrm{CH} 0$ or 1$)$ in the GIS:

$$
\mathrm{DT}=\left(\mathrm{CF}-\mathrm{K}_{\mathrm{S}}\right) \sin (\mathrm{S}) \mathrm{CH}
$$

Next, the transport capacity ( $\mathrm{G}$ in $\mathrm{kg} / \mathrm{m}^{2}$ ) is computed according to De Jong et al., (1999) from the distributed transport capacity (DT), slope $(\mathrm{S})$ and vegetation factor $\mathrm{C}$ proposed by Alejandro and Omasa, (2007):

$$
\mathrm{G}=0.001 * \mathrm{C}^{*} \mathrm{DT}^{1.7} * \sin (\mathrm{S})
$$

After that calculated transport capacity $(\mathrm{G})$, The splash detachment rate $\left(\mathrm{F}\right.$ in $\left.\mathrm{kg} / \mathrm{m}^{2}\right)$ is derived from the soil detachability index ( $\mathrm{K}$ in $\mathrm{g} / \mathrm{J})$ and rainfall interception factor (P in \%):

$$
\mathrm{F}=0.001 \mathrm{~K}(\mathrm{E} \exp (0.05 \mathrm{P}))
$$

The interception factor is estimated from a spectral vegetation index $\left(\mathrm{V}_{\mathrm{i}}\right)$. For this study, the normalized difference vegetation index (NDVI) and Linear Spectral Mixing Analysis (LSMA) technique used to calculate spectral vegetation index $\left(\mathrm{V}_{\mathrm{i}}\right)$.

Interception $P$ is calculated by overturning the exponential fit between $\mathrm{Pi}$ and the spectral index $\mathrm{V}_{\mathrm{i}}$ according to De Jong et al., (1999):

$$
\mathrm{V}_{\mathrm{i}}=\mathrm{a}(1-\exp (-\mathrm{b} \mathrm{P}))+\mathrm{c}
$$

$\mathrm{a}, \mathrm{b}$ and $\mathrm{c}$ definite model coefficients are taken from the De Jong (1994). After that calculate, the final soil loss predictions are computed by comparing the predictions of detachment by splash $\left(\mathrm{F}\right.$ in $\left.\mathrm{kg} / \mathrm{m}^{2}\right)$ and the transport capacity $\left(\mathrm{G} \mathrm{kg} / \mathrm{m}^{2}\right)$ of the overland flow. The minor of the two values is allocated as the yearly soil loss (t/ha/yr) rate:

Mean annual soil loss $=$ Minimize $(F, G)$

\section{Comparison of sediment yield estimates}

For this study, Linear Spectral Mixture Analysis (LSMA) and Normalized Difference Vegetation Index (NDVI) technique used for C- factor estimation. Using this two method, the rate of transport capacity of overland flow $\left(\mathrm{G}\right.$ in $\left.\mathrm{kg} / \mathrm{m}^{2}\right)$ and soil detachment by raindrop power $\left(\mathrm{F}\right.$ in $\mathrm{kg} / \mathrm{m}^{2}$ ) were computed for the year of 2008 and 2015. Then equate the values of the derived $F$ and $G$ for the year of 2008 and 2015. Then allocated the minor value as yearly soil sediment (t/ha/yr).

\section{Results and Discussion}

\section{C factor estimation map}

Linear spectral mixture analysis (LSMA) derived $\mathrm{C}$ - factor map

Figure 3 to 11 shows the fraction images derived using the LSMA for agriculture, bare soil, forest and water end-members for the year of 2008 and 2015. A high abundance of each end-member is specified by bright pixels and a low abundance by the darker pixels. The fraction image shows that agriculture dominates the study area. A bright pixel shows the agriculture, a forest and water bodies and Darker pixel shows the wasteland area.

\section{Normalized difference vegetation index} (NDVI) derived C- factor map

The NDVI expresses the difference between reflectance in the red and near infrared (nir) bands. For a LISS III, the NDVI was calculated using band 2 (RED) and band 3 (NIR). Fig. 12 and Fig. 13 shows the derived Normalized Difference Vegetation Index (NDVI). From the preparation of NDVI map, the maximum and minimum values found for the study area are -0.4285 and $0.6666(\%)$ for the year of 2008. For the year of 2015, the minimum and maximum values are -0.0085 
and $0.6744(\%)$. The NDVI values were used to calculate the C-factor for the year of 2008 and 2015. The transport capacity and splash detachment rate map for the year of 2008 and the 2015 were prepared using the $\mathrm{C}$-factor values derived from the NDVI.

\section{Model development}

\section{Water segment}

The kinetic energy of rainfall $(\mathrm{J} / \mathrm{m} 2)$ and volume of cumulative overland flow ( $\mathrm{mm}$ ) were estimated in the water segment.

\section{Rainfall energy}

Kinetic energy of rainfall $(E)$ is dependent on the amount of mean yearly precipitation $(R)$ and rain intensity (I). Total yearly precipitations $(\mathrm{R})$ for the study area were observed as 531.7 and $756 \mathrm{~mm}$ for the year of 2008 and 2015 respectively. Intensity of erosive rain (I) was considered as 21.81 and $31.41 \mathrm{~mm} / \mathrm{hr}$ for the 2008 and 2015 respectively. Rain energy (E) was calculated as 6518.27 and $9071.84 \mathrm{~J} / \mathrm{m} 2$ for the year of 2008 and 2015 respectively.

\section{Cumulative flow}

The generated cumulative flow map for the year of 2008 and 2015 are as shown in Fig. 14 and Fig. 15 respectively. Figures show that the lower values of the cumulative flow are 0 and 0 and higher values of cumulative flow are 2107.59 and $2189.47 \mathrm{~mm}$ for the year of 2008 and 2015 respectively. There are minor changes of the flow between the year 2008 and 2015.

\section{Sediment phase}

In the sediment phase, average transport capacity of overland flow ( $\mathrm{G}$ in $\mathrm{Kg} / \mathrm{m} 2$ ) and average rate of splash detachment $(\mathrm{F}$ in
$\mathrm{Kg} / \mathrm{m} 2$ ) were computed and maps were generated for the two years of 2008 and 2015. After comprised of these two map, the minimum value of pixel was taken into account for the soil loss of the watershed.

\section{Transport capacity of overland flow ( $G$ in $\mathrm{kg} / \mathbf{m}^{2}$ )}

The preparations of LSMA and NDVI derived transport capacity map, the minimum and maximum values are $-0.042 \& 0.1874$ and $0.072 \& 0.2232(\mathrm{~kg} / \mathrm{m} 2)$ respectively for the year of 2008. The preparations of LSMA and NDVI derived transport capacity map, the minimum and maximum values are $-0.040 \&$ 0.1912 and $-0.0071 \& 0.1953 \quad(\mathrm{~kg} / \mathrm{m} 2)$ respectively for the year of 2015 . The minus values of LSMA and NDVI derived transport capacity indicated the detachment of soil by splash detachment rate. The plus values indicated the sediment accumulation in the watershed. The sediment delivered with the cumulative flow from upslope to down slope of the study area. The generated map of LSMA and NDVI are shows in Fig. 16 to Fig. 19.

The amount of generated total sediment for LSMA and NDVI were $1.13 \& 1.35 \mathrm{~kg} / \mathrm{m} 2$ and $1.40 \& 1.52 \mathrm{~kg} / \mathrm{m} 2$ in the year of 2008 and 2015 respectively. The total sediment estimated for LSMA and NDVI in tonnes were $11.32 \mathrm{t} / \mathrm{ha} / \mathrm{yr} \& 13.53 \mathrm{t} / \mathrm{ha} / \mathrm{yr}$ and 14.01 t/ha/yr \& $15.20 \mathrm{t} / \mathrm{ha} / \mathrm{yr}$ for the year of 2008 and 2015 respectively.

The derived values of transport capacity for the NDVI were higher than the LSMA technique for the year of 2008 and 2015. Hence, NDVI derived value overestimated the transport capacity $(\mathrm{G})$. Again by comparing the results of year 2008 and 2015, the transport capacity in the year of 2015 is higher than the year of 2008. The probable reason for increase in transport capacity may 
be the deforestation and increase the agriculture and barren land certain the year of 2015.

\section{Splash detachment rate ( $\mathrm{F}$ in $\left.\mathrm{Kg} / \mathrm{m}^{2}\right)$}

In the LSMA and NDVI derived splash detachment rate map, the minimum and maximum values are $1.66 * \mathrm{e}^{-5} \& 5.39 * \mathrm{e}^{-5}$ and $1.25 * \mathrm{e}^{-8} \& 8.9 * \mathrm{e}^{-5}\left(\mathrm{~kg} / \mathrm{m}^{2}\right)$ respectively for the year of 2008. In the LSMA and NDVI derived splash detachment rate map, the minimum and maximum values are $1.41 * \mathrm{e}^{-5}$ $\& 3.93 * \mathrm{e}^{-5}$ and $7.82 * \mathrm{e}^{-9} \& 8.07 \mathrm{e}^{-5}\left(\mathrm{~kg} / \mathrm{m}^{2}\right)$ respectively for the year of 2015. The generated map of LSMA and NDVI are shows in Fig. 20 to Fig. 22. The amount of generated total sediment for LSMA and NDVI were $6.28 \& 7.72 \mathrm{~kg} / \mathrm{m}^{2}$ and $8.36 \&$ $8.82 \mathrm{~kg} / \mathrm{m}^{2}$ in the year of 2008 and 2015 respectively. The derived values of splash detachment rate of the watershed for the NDVI were higher than the LSMA technique for the year of 2008 and 2015. Again by comparing the results of year 2008 and 2015, the splash detachment rate in the year of 2015 is higher than the year of 2008 .

Table.1 Values of the using LSMA and NDVI derived as input to SEMMED

\begin{tabular}{|c|c|c|c|c|}
\hline \multirow{2}{*}{ Year } & \multicolumn{2}{|c|}{ LSMA } & \multicolumn{2}{c|}{ NDVI } \\
\cline { 2 - 5 } & $\mathrm{G}\left(\mathrm{Kg} / \mathrm{m}^{2}\right)$ & $\mathrm{F}\left(\mathrm{Kg} / \mathrm{m}^{2}\right)$ & $\mathrm{G}\left(\mathrm{Kg} / \mathrm{m}^{2}\right)$ & $\mathrm{F}\left(\mathrm{Kg} / \mathrm{m}^{2}\right)$ \\
\hline $\mathbf{2 0 0 8}$ & 1.13 & 6.28 & 1.40 & 7.72 \\
\hline $\mathbf{2 0 1 5}$ & 1.35 & 8.36 & 1.52 & 8.82 \\
\hline
\end{tabular}

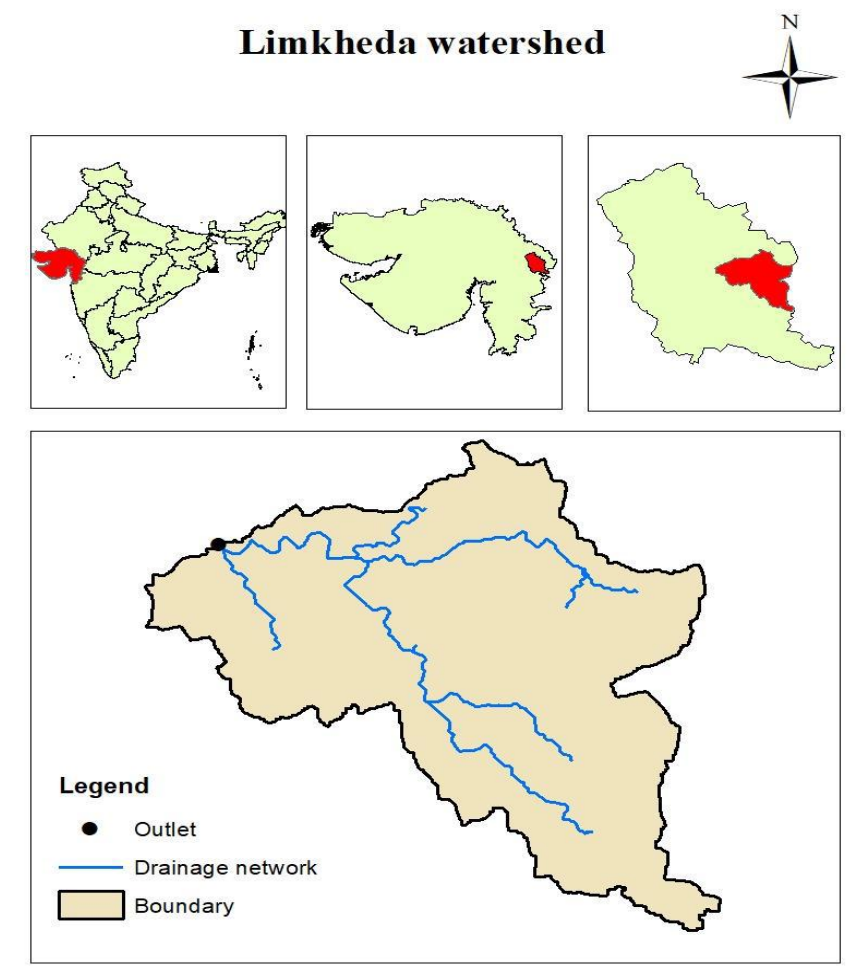

Fig.1 Location map of the study area (Limkheda Watershed) 


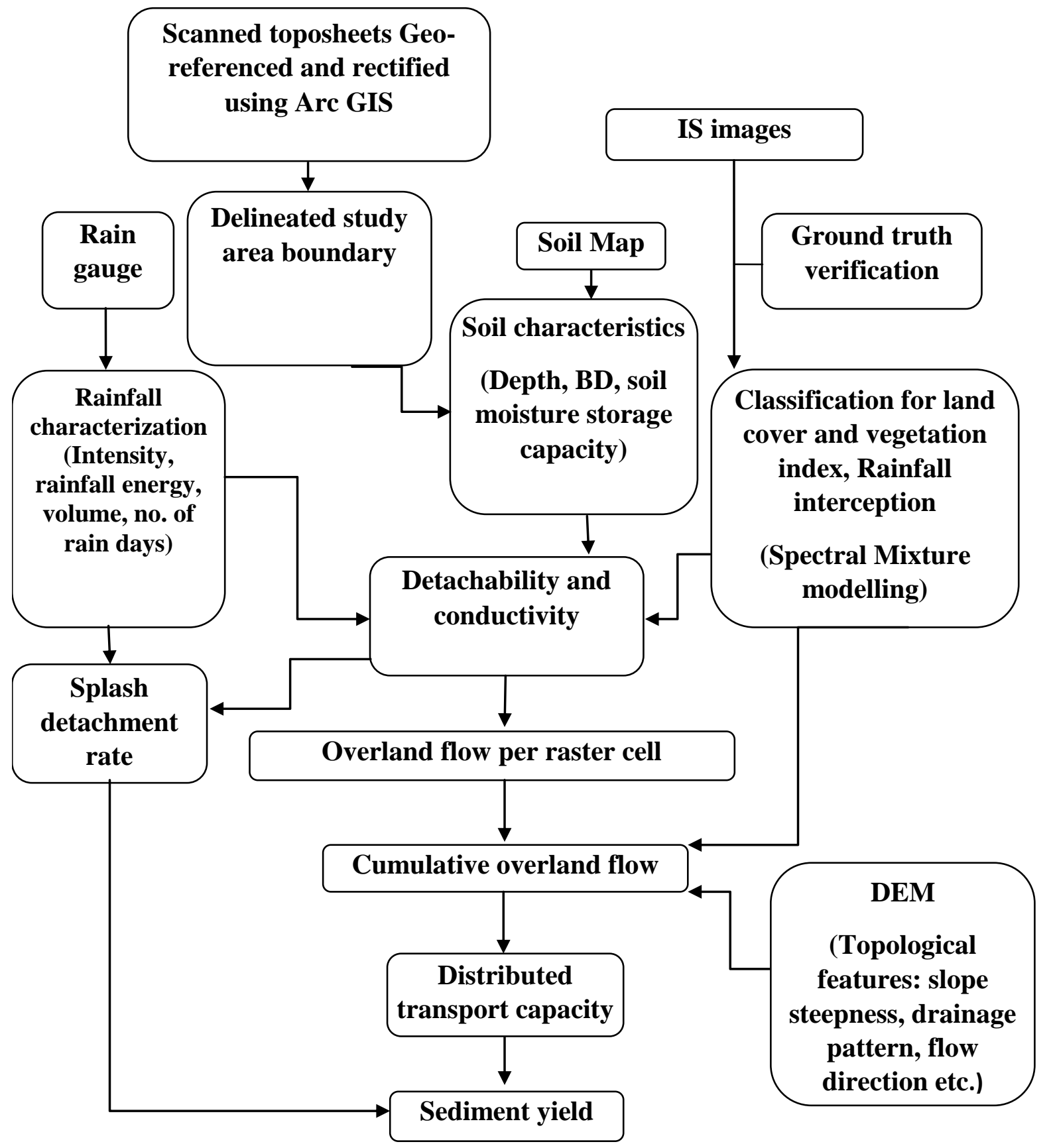

Fig.2 Flow chart showing the methodology to estimate sediment yield using spectral mixture modelling technique 


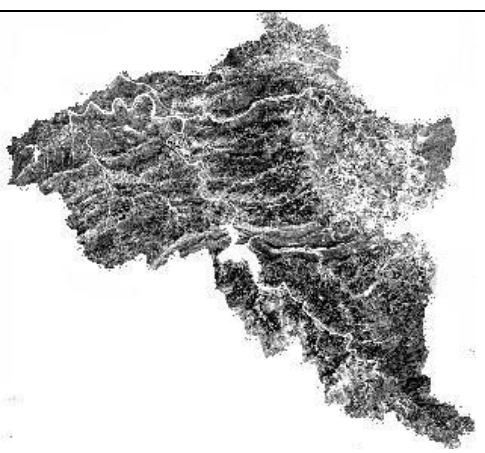

Fig.3 Fraction of waterbodies Year

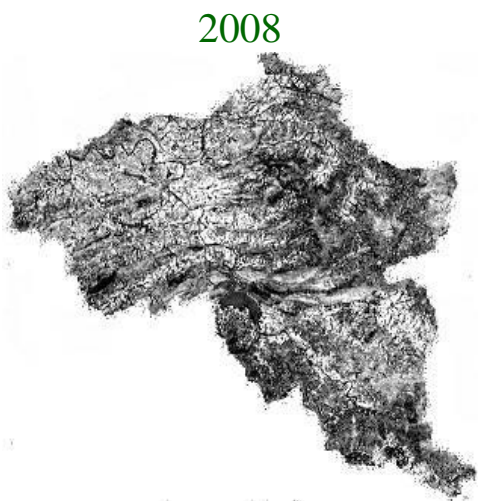

Fig.5 Fraction of agriculture in year

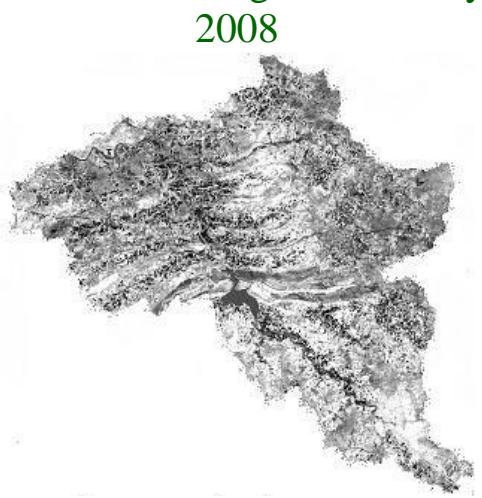

Fig.7 Fraction of forest in year 2008

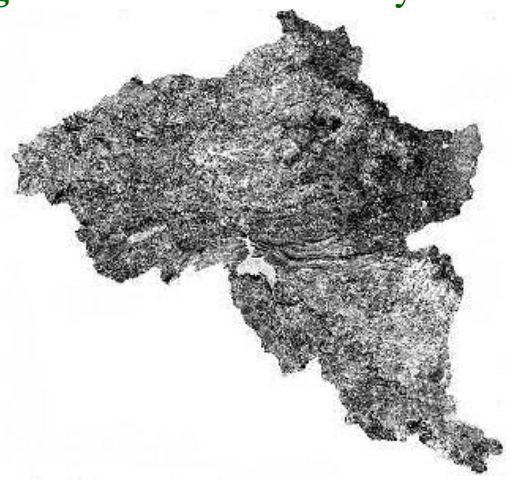

Fig.9 Fraction of waste land in year 2008

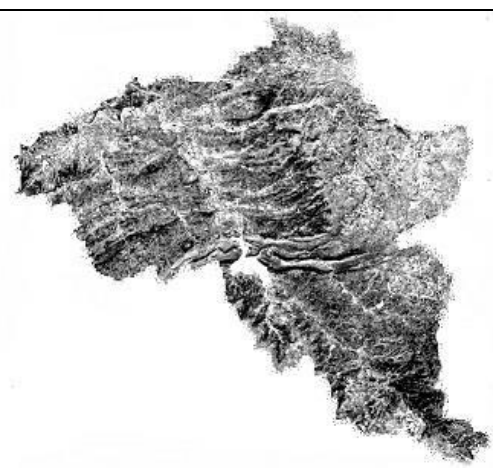

Fig.4 Fraction of waterbodies in Year

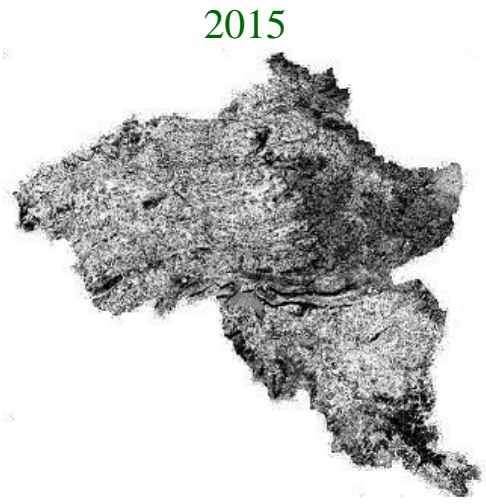

Fig.6 Fraction of agriculture in year 2015

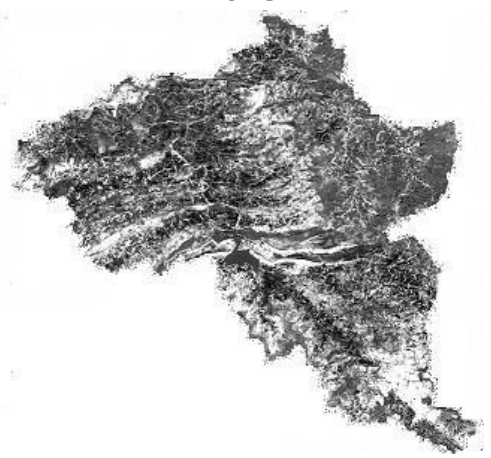

Fig.8 Fraction of forest in year 2015

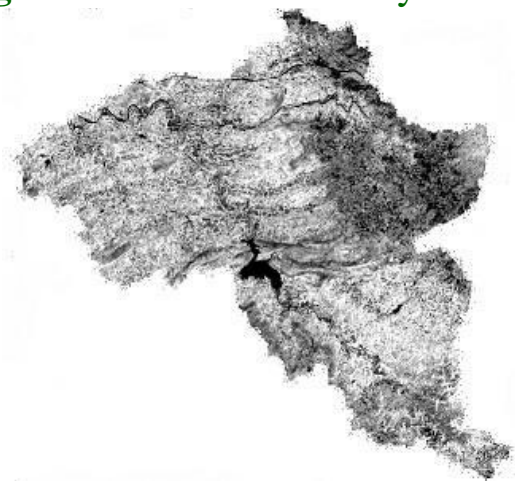

Fig.10 Fraction of waste land in year 2015 


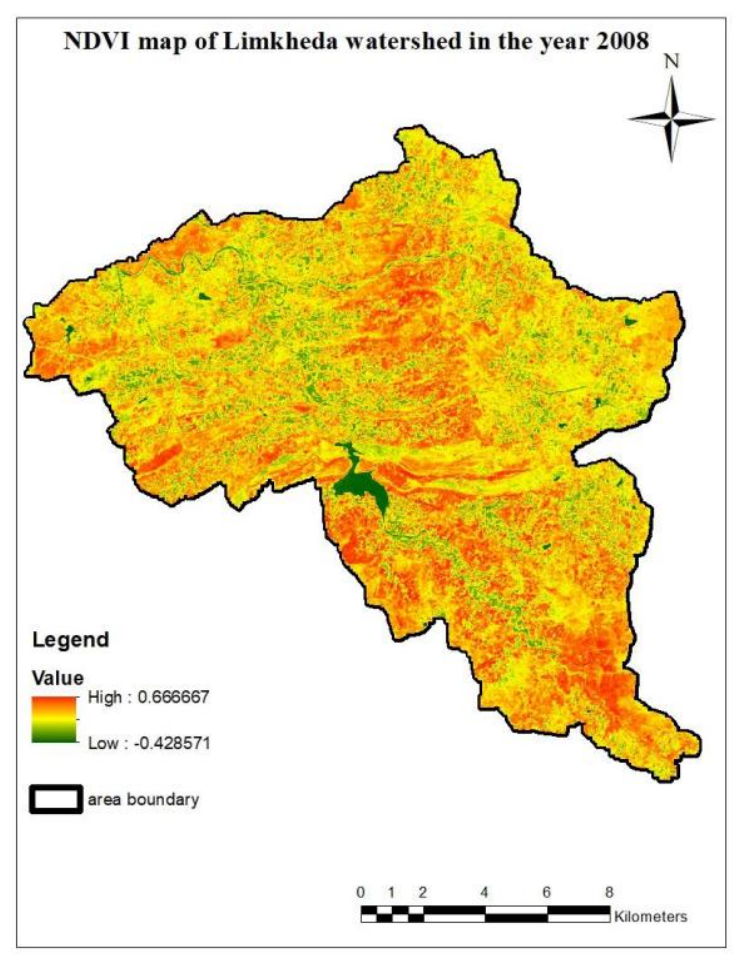

Fig.11 NDVI map of Limkhedawatershed in the year 2008

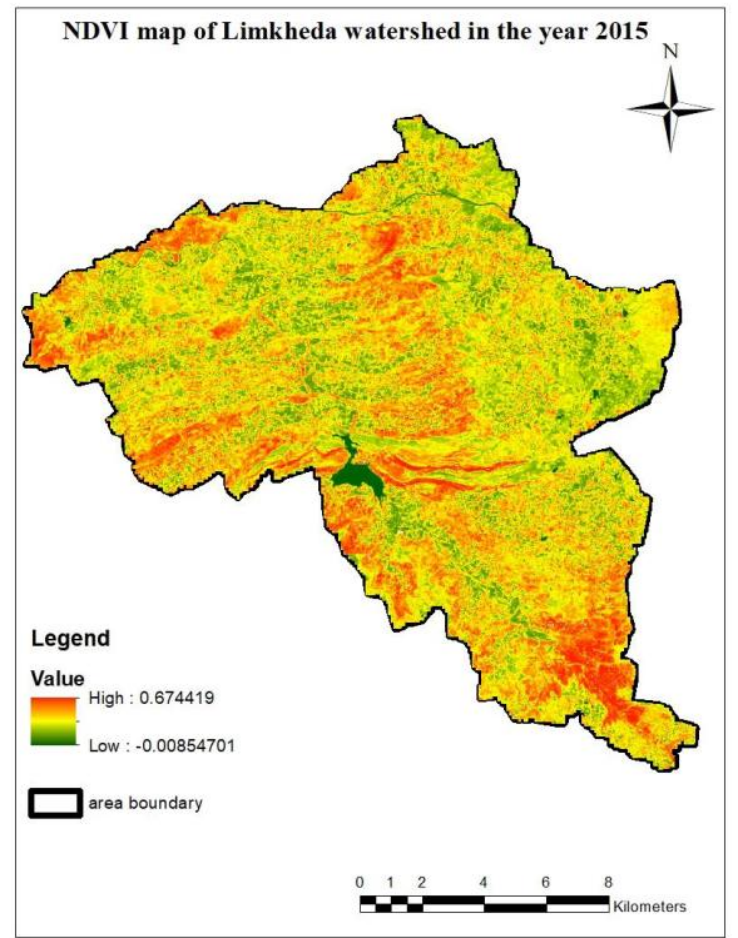

Fig.12 NDVI map of Limkheda watershed in the year 2015

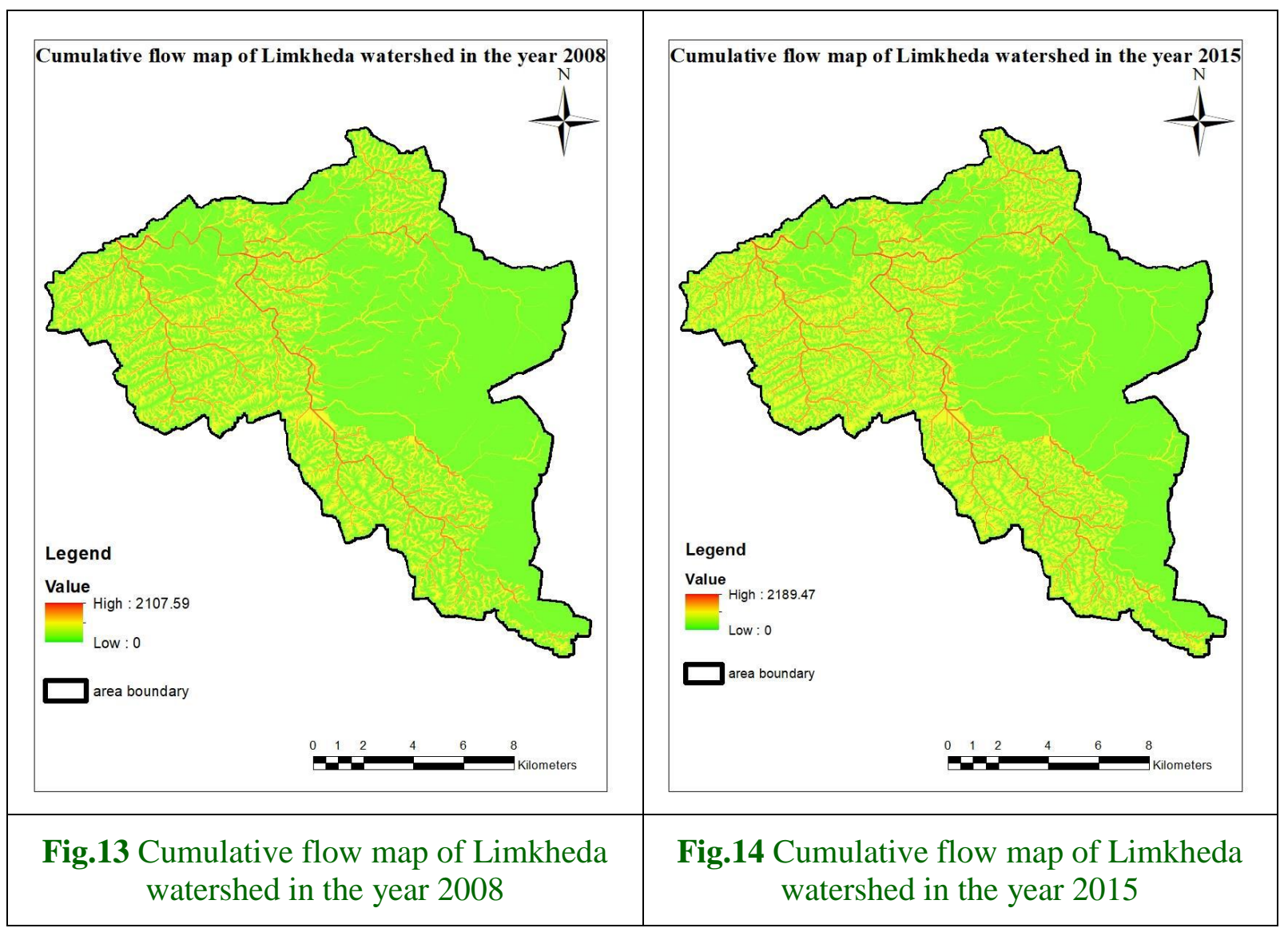




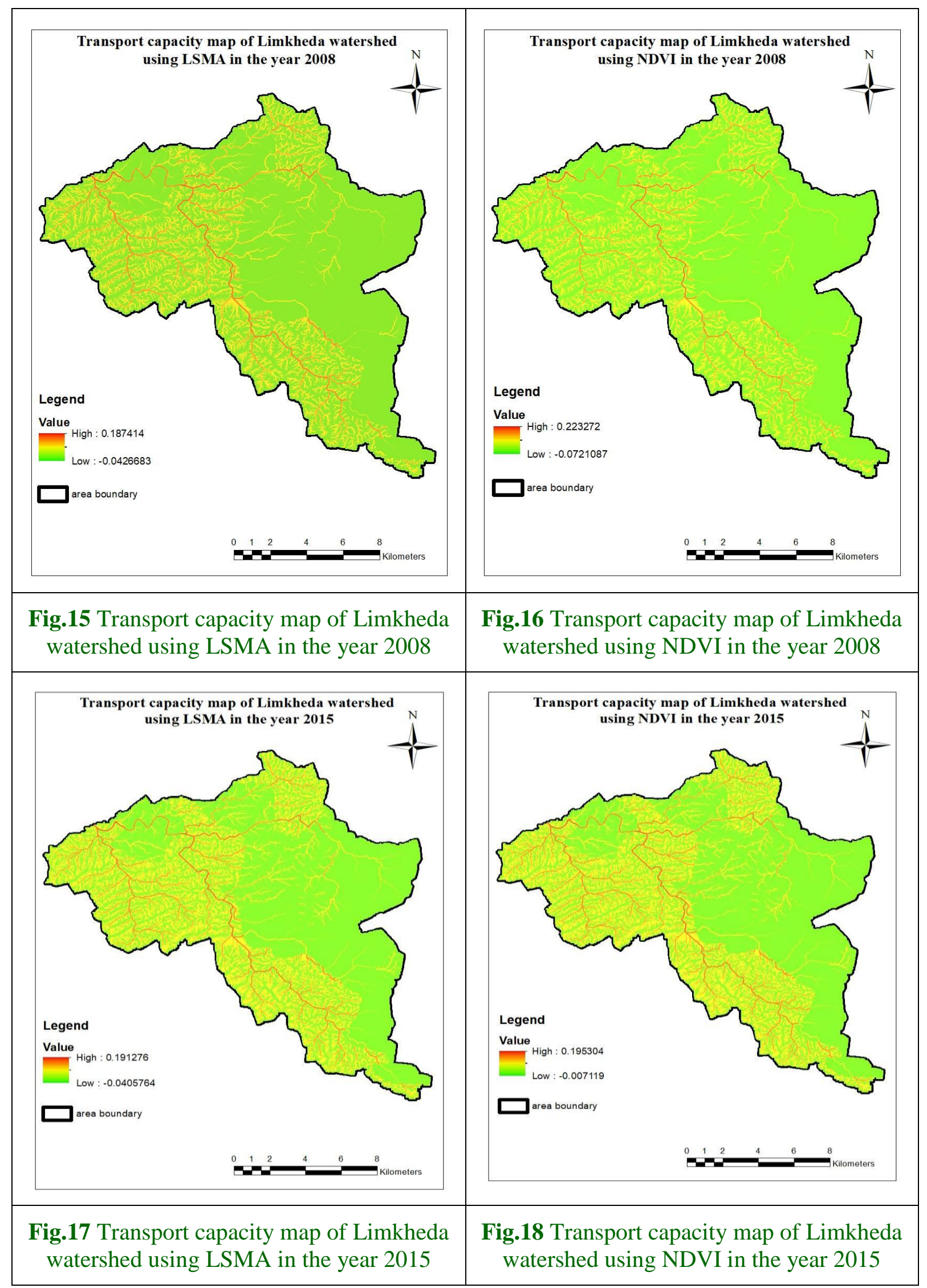




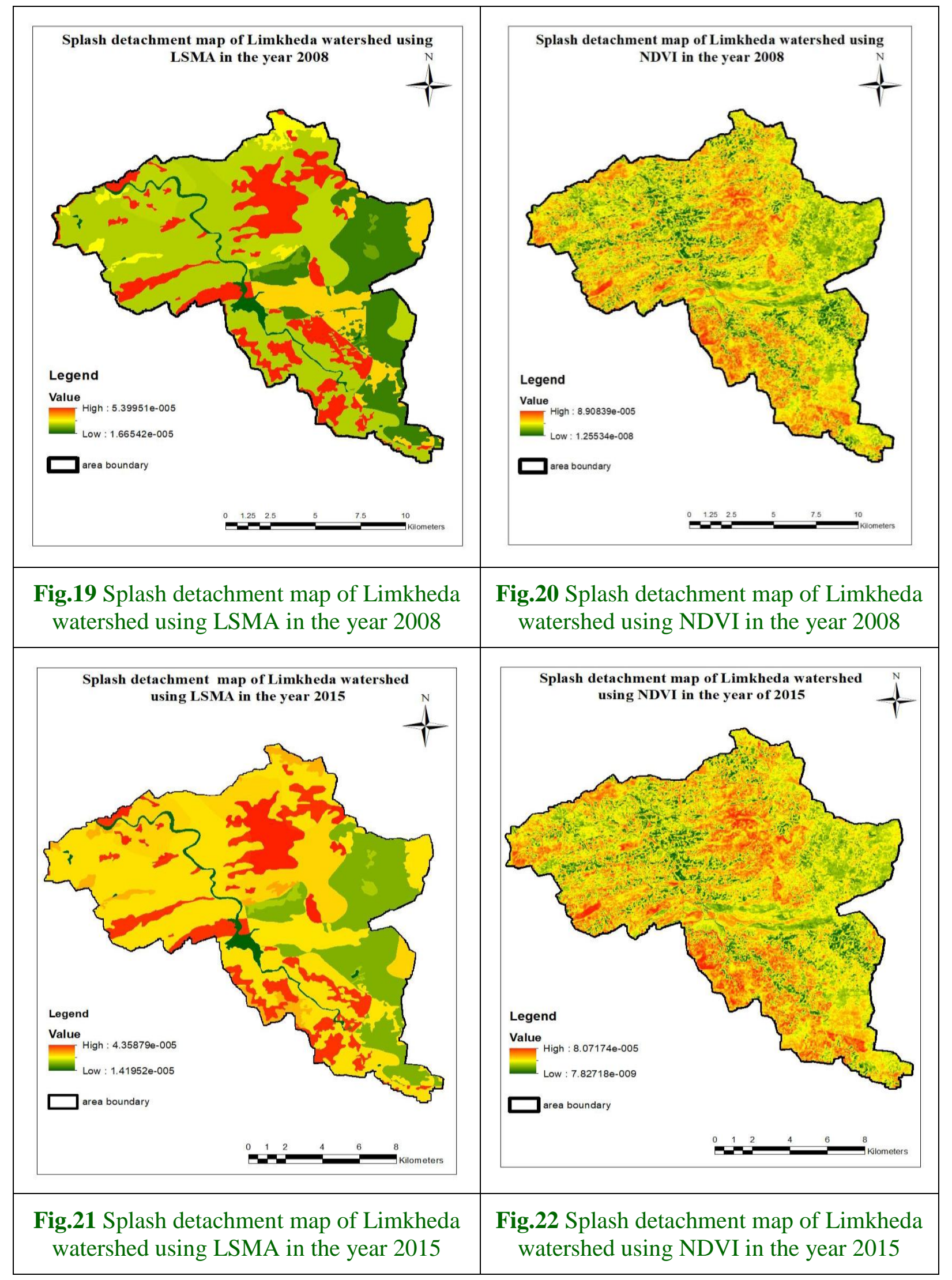




\section{Comparison of sediment yield estimates}

The rate of transport capacity of overland flow $\left(\mathrm{G}\right.$ in $\left.\mathrm{kg} / \mathrm{m}^{2}\right)$ and soil detachment by raindrop impact $\left(\mathrm{F}\right.$ in $\left.\mathrm{kg} / \mathrm{m}^{2}\right)$ were computed using derived C- factor for the year of 2008 and 2015. Then comprises the values of the derived $F$ and $G$ using Linear Spectral Mixture Analysis (LSMA) and Normalized Difference Vegetation Index (NDVI) for the year of 2008 and 2015. The derived value of $\mathrm{F}$ and $\mathrm{G}$ are shown in table 1 . The value of transport capacity $(\mathrm{G})$ was lower than the splash detachment rate $(F)$. So the transport capacity $(\mathrm{G})$ values assigned as the annual sediment.

Soil loss predicted by SEMMED model range from 0 to $9.76 \mathrm{~kg} / \mathrm{m}^{2} / \mathrm{yr}$. The assessment of the model results can be presented in two ways by considering the (1) Linear Spectral Mixture Analysis (LSMA) (2) Normalized Difference Vegetation Index (NDVI) for Cfactor estimation for year of 2008 and 2015. From the table, the derived values of transport capacity for the NDVI are higher than the LSMA technique. Again by comparing the results of the year 2008 and 2015, the transport capacity in the year of 2015 is higher than the year of 2008 and the derived values of transport capacity for the LSMA is higher than the NDVI technique for the year of 2015.

By comparing the results of year 2008 and 2015, the splash detachment rate of 2015 is higher in LSMA case and lower in the NDVI case than the year of 2008. Hence, the total sediment estimated for LSMA and NDVI in tonnes were $11.32 \mathrm{t} / \mathrm{ha} / \mathrm{yr} \& 13.53 \mathrm{t} / \mathrm{ha} / \mathrm{yr}$ and $14.01 \mathrm{t} / \mathrm{ha} / \mathrm{yr} \& 15.20 \mathrm{t} / \mathrm{ha} / \mathrm{yr}$ for the year of 2008 and 2015, respectively.

This study evaluated the suitability of the LSMA method to assess vegetation and ground cover to derive up-to-date $\mathrm{C}$ factors.
The amount of generated total sediment using LSMA was better estimated than the commonly used method NDVI. SEMMED model was well predicted the amount of sediment yield and this is very much efficient and time saving and yielded reasonable amount of sediment for small watershed area. The model and LSMA technique produces satisfactory estimates of sediment yield for entire watershed from the obtained results observation.

\section{References}

Alejandro, M., \& Omasa, K. (2007). Estimation of vegetation parameter for modeling soil erosion using linear Spectral Mixture Analysis of Landsat ETM data. ISPRS Journal of Photogrammetry and Remote Sensing, 62(4), 309 - 324.

Bagherzadeh, A., \& Daneshvar, M. R. M. (2013). Evaluation of sediment yield and soil loss by the MPSIAC model using GIS at Golestan watershed, northeast of Iran. Arabian Journal of Geosciences, 6(9), 3349 - 3362.

Batista, P. V. G., Silva, M. L. N., Silva, B. P. C., Curi, N., Bueno, I. T., Júnior, F. W. A., \& Quinton, J. (2017). Modelling spatially distributed soil losses and sediment yield in the upper Grande River BasinBrazil. Catena, 157, 139 - 150.

Beasley, D. B., Huggins, L. F., \& Monke, A. (1980). ANSWERS: A model for watershed planning. Transactions of the ASAE, 23(4), 938 - 944.

Behera, B. P. (2003). Modeling Sediment Yield Of River Ib Basin To Study Its Effect On Hirakud Reservoir (Doctoral dissertation, Indian Agricultural Research Institute; New Delhi). Retrieved from http://krishikosh.egranth.ac.in/bitstream/1/5 810008181/1/7233

Beskow, S., Mello, C. R., Norton, L. D., Curi, N., Viola, M. R., \& Avanzi, J. C. (2009). Soil erosion prediction in the Grande River Basin, Brazil using distributed modeling. Catena, 79(1), 49 - 59. 
De Asis, A. M., Omasa, K., Oki, K., \& Shimizu, Y. (2008). Accuracy and applicability of linear spectral unmixing in delineating potential erosion areas in tropical watersheds. International Journal of Remote Sensing, 29(14), 4151 - 4171.

De Jong, S. M., Paracchini, M. L., Bertolo, F., Folving, S., Megier, J., \& De Roo, A. P. J. (1999). Regional assessment of soil erosion using the distributed model SEMMED and remotely sensed data. Catena, 37(3-4), 291 - 308.

De Vente, J., Poesen, J., \& Verstraeten, G. (2005). The application of semi-quantitative methods and reservoir sedimentation rates for the prediction of basin sediment yield in Spain. Journal of Hydrology, 305(1-4), 63 86.

De Vente, J., Poesen, J., Bazzoffi, P., Rompaey, A. V., \& Verstraeten, G. (2006). Predicting catchment sediment yield in Mediterranean environments: the importance of sediment sources and connectivity in Italian drainage basins. Earth surface processes and landforms, 31(8), 1017 - 1034.

Ichoku, C., \& Karnieli, A. (1996). A review of mixture modeling techniques for sub- pixel land cover estimation. Remote sensing reviews, 13(3-4), 161 - 186.

Mertes, L. A., Smith, M. O., \& Adams, J. B. (1993). Estimating suspended sediment concentrations in surface waters of the Amazon River wetlands from Landsat images. Remote Sensing of Environment, 43(3), 281-301.

Morgan, R. P. C. (1998). The European soil erosion model (EUROEM). A Process based approach for predicting soil loss from fields and small catchments. Earth Surface Processes Landforms, 23(6), 527-544.

Nearing, M. A., Foster, G. R., Lane, L. J., \&
Finkner, S. C. (1989). A process-based soil erosion model for USDA-Water Erosion Prediction Project technology. Transactions of the ASAE, 32(5), 1587 - 1593.

$\mathrm{Qu}$, L. (2014). Remote sensing suspended sediment concentration in the Yellow River (Doctoral dissertation, University of Connecticut Graduate School). Retrieved from

https://opencommons.uconn.edu/dissertatio $\mathrm{ns} / 383$

Qu, L., Lei, T., Ning, D., Civco, D., \& Yang, X. (2016). A spectral mixing algorithm for quantifying suspended sediment concentration in the Yellow River: a simulation based on a controlled laboratory experiment. International Journal of Remote Sensing, 37(11), 2560 - 2584.

Srinivasa Rao, K. (2012). soil erosion estimation of Godavari basin using Remote Sensing and Geographical Information Systems (GIS) techniques (Doctoral dissertation, Acharya NG Ranga Agricultural University). Retrieved from http://krishikosh.egranth.ac.in/handle/1/669 65

Williams, J. R., Jones, C. A., \& Dyke, P. T. (1984). A modeling approach to determining the relationship between erosion and soil productivity. Transactions of the ASAE, 27(1), 129 - 0144.

Woolhiser D.A., Smith, R.E and Goodrich, D.C. (1990). KINEROS, A kinematic runoff and erosion model: documentation and user manual. USDA-Agricultural ResearchService, ARS-77: $130 \mathrm{p}$.

Young, R. A. (1987). AGNPS, Agricultural Non-Point-Source Pollution Model: a watershed analysis tool. Conservation research report (USA). no. 35.

\section{How to cite this article:}

Ghetiya. J. M. and Patel. G. R. 2020. Comparative Performance of Linear Spectral Mixture \& NDVI Technique by Mapping Sediment Yield using Semmed Model. Int.J.Curr.Microbiol.App.Sci. 9(04): 1656-1670. doi: https://doi.org/10.20546/ijcmas.2020.904.194 